\title{
The Meaning of Kei Proverbs in Behavior of the People
}

\author{
$1^{\text {st }}$ Margaretha Febriany Narahawarin* \\ Department of English Literature \\ Universitas Musamus \\ Merauke, Indonesia \\ narahawarin_fkip@unmus.ac.id
}

\author{
$2^{\text {nd }}$ Sri Winarsih \\ Department of English Literature \\ Universitas Musamus \\ Merauke, Indonesia \\ sriwinarsih@unmus.ac.id
}

\author{
$3^{\text {rd }}$ Natalia Manuhutu \\ Department of English Literature \\ Universitas Musamus \\ Merauke, Indonesia \\ manuhutu_fkip@unmus.ac.id
}

\begin{abstract}
The content of each culture can be expressed in language. Understanding to idioms and special expressions a language can to express the people habits and the way of thinking. That is through in vocabulary, figurative language, or metaphors of a language can be understood the culture of native speakers. Figurative language in culture o ethnic Kei is a proverbs, so this study aims to knowing relationship of language and culture, in this case how to Kei people describe his world which is reflected in proverbs. This study is a qualitative ethnolinguistic research method with the data sources from traditional leaders who knows well the language and culture of ethnic Kei, the data Obtained then Analyzed using content analysis approach. The result shows the meaning of Kei proverbs reflected in behavior of the people is divided into three parts; 1) Character of the people, 2) the people with their behavior, 3 ) the people with around situation.
\end{abstract}

Keywords: meaning, proverbs of kei, culture, behavior of the people

\section{INTRODUCTION}

Language is seen as the means to understand the culture, or in other words without language a culture can not be understood. Related between language and culture always found together, interplay, and filling each other [1]. Cultural values of verbal are preserved in the form of riddles, songs, stories, fairy tales, legends poems, epics and ballads [2]. Proverb is the essence of the wisdom and knowledge of tribes (ethnic) and used exstensively in verbal culture [3]. Proverb has an effect on the way of thinking in the people as an instrument for teaching and education [4]. From the explanations above, it can be concluded the culture can be understood through proverbs, metaphors, and vocabulary [5] of language.

Generally, proverb means to delivery something indirectly message. The messages contains social norms regarding the various phenomenon its essence to described principles of life harmony of the people. This harmony of life to illustrates the human attitudes dealing with each other and the events that surround them.

Kei is one of the islands in Southeast Maluku area. Kei islands (Nuhu Evav) has separate culture and language that still preserved, one of which is proverbs. Proverbs of Kei as manifestation of the value of life people to give expressions in various aspects of life including to ethics, morals, attitudes, education, and so on in suitable with customary law of Larwul Ngabal [6]. The aspects of life gets different suppression suitable with the element referenced in proverbs of Kei. Proverbs of Kei need to be studied from various aspects, namely aspects of language and culture so this study aims to describe the meaning of Kei figurative language in behavior of the life people.

\section{RESEACRH METHODS}

This study is a qualitative study using ethnolinguistic research methods are qualitative. Sources of the data obtained from traditional leader who knows well the language and culture of ethnic Kei. In the data collecting, researchers obtained the data from the literature of Kei figurative language and also conducted observations which complete with interview.

\section{RESUltS AND DisCUSSION}

Proverb is a short language expression, solid, and short of statements, opinions, or a general truth [7]. As an expression of solid, proverb is reflect to cultural values and ideas of the people about the environment and what is happening around them. Proverb is basically to contains original concepts from ethnic Kei reflects their way of thinking which suppose that through three parts; Character of The People, The People with their behavior, The People with Around Situation. In every data display of proverb there is Kei proverb, the meaning of Kei proverbs in Indonesia [8] proverbs, and the meaning of Kei proverbs in English language.

\section{A. Character of The People}

In character of the people found two kinds of the character people which reflected in Kei proverbs, namely the good character and the bad character. Every data can be seen in the following table.

TABLE I. DATA DISPLAY FROM PROVERBS OF KEI IN CHARACTER OF THE PEOPLE

\begin{tabular}{|l|l|l|l|}
\hline $\begin{array}{c}\text { Character } \\
\text { of the } \\
\text { people }\end{array}$ & $\begin{array}{l}\text { Proverbs of kei } \\
\text { (Kei language) }\end{array}$ & $\begin{array}{c}\text { Meaning } \\
\text { (Indonesia } \\
\text { language) }\end{array}$ & \multicolumn{1}{|c|}{$\begin{array}{c}\text { Meaning } \\
\text { (English } \\
\text { language) }\end{array}$} \\
\hline $\begin{array}{l}\text { The good } \\
\text { character }\end{array}$ & $\begin{array}{l}\text { Nanar afa fel } \\
\text { horngain }\end{array}$ & $\begin{array}{l}\text { tutur katanya } \\
\text { seperti tangkai } \\
\text { tombak }\end{array}$ & $\begin{array}{l}\text { The person } \\
\text { who speaks } \\
\text { honestly }\end{array}$ \\
\cline { 2 - 4 } & $\begin{array}{l}\text { Amalir endok } \\
\text { wat roa ne sar }\end{array}$ & $\begin{array}{l}\text { bangsal di pinggir } \\
\text { pantai dan }\end{array}$ & $\begin{array}{l}\text { The people } \\
\text { who like to }\end{array}$ \\
\hline
\end{tabular}




\begin{tabular}{|l|l|l|l|}
\cline { 2 - 4 } & endok ded ratan & $\begin{array}{l}\text { pondok di pinggir } \\
\text { jalan }\end{array}$ & $\begin{array}{l}\text { help without } \\
\text { partial }\end{array}$ \\
\hline $\begin{array}{l}\text { The bad } \\
\text { character }\end{array}$ & $\begin{array}{l}\text { Ivun ain ru ne } \\
\text { raan ain tel }\end{array}$ & $\begin{array}{l}\text { perutnya dua } \\
\text { bagian dan } \\
\text { hatinya tiga } \\
\text { bagian }\end{array}$ & $\begin{array}{l}\text { what is the said } \\
\text { opposite of his } \\
\text { heart }\end{array}$ \\
\cline { 2 - 4 } & Nablo fel saribat & lurus seperti keris & $\begin{array}{l}\text { the people who } \\
\text { underhanded }\end{array}$ \\
\hline
\end{tabular}

In table 1 , shows that every behavior of the people in ethnic Kei [9] is illustrated through different by the proverbs. Character of the people being good and bad in proverbs of Kei stated by declarative sentences [10]. Declarative sentences have the quality statement summary and clear. If the statement referred to an element or a normal situation then proverbs categorized as a good character. But if the referenced to stated a situation that is contradict with the situation, it is categorized as bad character.

\section{B. The People With Their Behavior}

In the people with their behavior found two kinds of the people with their behavior which reflected in proverb of Kei, namely positive behavior and negative behavior. Every data can be seen in the following table.

TABLE II. DATA DISPLAY KEI PROVERB OF KEI IN THE PEOPLE WITH THEIR BEHAVIOR

\begin{tabular}{|c|c|c|c|}
\hline $\begin{array}{l}\text { The people } \\
\text { with their } \\
\text { behavior }\end{array}$ & $\begin{array}{c}\text { Proverbs } \\
\text { of kei } \\
\text { (Kei } \\
\text { language) }\end{array}$ & $\begin{array}{c}\text { Meaning } \\
\text { (Indonesia language) }\end{array}$ & $\begin{array}{l}\text { Meaning } \\
\text { (English } \\
\text { language) }\end{array}$ \\
\hline \multirow[t]{2}{*}{$\begin{array}{l}\text { Positive } \\
\text { behavior }\end{array}$} & $\begin{array}{l}\text { Wu'ut ain } \\
\text { mehe } \\
\text { ngifun, ne } \\
\text { manut ain } \\
\text { mehe tilur }\end{array}$ & $\begin{array}{l}\text { telur dari satu ikan dan } \\
\text { satu ayam }\end{array}$ & $\begin{array}{l}\text { the people } \\
\text { come from one } \\
\text { ancestor }\end{array}$ \\
\hline & $\begin{array}{l}\text { Tafau } \\
\text { did lar } \\
\text { entaha }\end{array}$ & $\begin{array}{l}\text { kita kawin dengan } \\
\text { aliran darah yang tepat }\end{array}$ & $\begin{array}{l}\text { in choosing a } \\
\text { life partner to } \\
\text { that attention to } \\
\text { blood flow }\end{array}$ \\
\hline \multirow[t]{2}{*}{$\begin{array}{l}\text { Negative } \\
\text { behavior }\end{array}$} & $\begin{array}{l}\text { Nifar } \\
\text { nakmi } \\
\text { fedan } \\
\text { atbak }\end{array}$ & $\begin{array}{l}\text { rumput kencing } \\
\text { mematikan tembakau }\end{array}$ & $\begin{array}{l}\text { subordinates } \\
\text { mistake can be } \\
\text { hurt good name } \\
\text { from the boss }\end{array}$ \\
\hline & $\begin{array}{l}\text { Belan } \\
\text { endok } \\
\text { belan ran }\end{array}$ & $\begin{array}{l}\text { perahu belang berada } \\
\text { dalam perahu belang }\end{array}$ & $\begin{array}{l}\text { subordinates } \\
\text { shows his } \\
\text { power is more } \\
\text { than his boss }\end{array}$ \\
\hline
\end{tabular}

In table 2, shows that positive behavior is a behavior recommended in suitable with custom law of the Kei people while negative behavior is the behavior of the people as contradict with the custom law.

Based on the proverbs above, it can be seen that negative behavior of the people proverb of kei is not expressed by imperative sentence but with a declarative sentence. Both expressed by declarative sentences. To differentiate positive behavior and negative behavior in proverb of kei can be seen from the statement of the symbol. Usually the symbol used something destructive or abnormal condition. They understand from the symbols used to describe the behavior.

\section{People with the around situation}

In the people with around situation found four kinds of the people with around situation which reflected in proverb of Kei, namely work and positive work, work and negative work, luck situation, and suffering situation. Every data can be seen in the following table.

In table 3, shows in addition to advice on character of the people and the behavior, proverb of kei also advised about the the people with around situation especially shows the work situation and positive or negative working, luck situation, and suffering situation. All the situations described using declarative sentences. To distinguish between these two situations can be seen from reference symbols are used. Reference of normal symbol situation showed positive situation while the reference symbol usually indicates a situation that is not a negative situation.

TABLE III. DATA DISPLAY FROM PROVERBS OF KEI IN THE PEOPLE WITH AROUND SITUATION

\begin{tabular}{|c|c|c|c|}
\hline $\begin{array}{c}\text { The } \\
\text { people } \\
\text { with } \\
\text { around } \\
\text { situation }\end{array}$ & $\begin{array}{c}\text { Proverbs of } \\
\text { kei } \\
\text { (Kei } \\
\text { language) }\end{array}$ & $\begin{array}{l}\text { Meaning } \\
\text { (Indonesia } \\
\text { language) }\end{array}$ & $\begin{array}{c}\text { Meaning } \\
\text { (English language) }\end{array}$ \\
\hline \multirow[t]{4}{*}{$\begin{array}{l}\text { Work and } \\
\text { positive } \\
\text { work }\end{array}$} & $\begin{array}{lr}\text { Tangun } & \text { ler } \\
\text { enan } & \text { ne } \\
\text { manga tu'el } \\
\text { adan tilur }\end{array}$ & $\begin{array}{lr}\text { kacang } & \text { hijau } \\
\text { kering dan } & \text { sagu } \\
\text { kering } & \end{array}$ & $\begin{array}{l}\text { make separation } \\
\text { before dong a job }\end{array}$ \\
\hline & $\begin{array}{l}\text { Kes tuv har fit } \\
\text { ne mav de rat }\end{array}$ & $\begin{array}{l}\text { bekal untuk tujuh } \\
\text { generasi dan } \\
\text { merantau seratus } \\
\text { malam }\end{array}$ & $\begin{array}{l}\text { prepare something } \\
\text { for long time period }\end{array}$ \\
\hline & $\begin{array}{l}A i \quad \text { ernem } \\
\text { vakbo }\end{array}$ & $\begin{array}{l}\text { kayu berkumpul } \\
\text { menjadir pagar } \\
\text { dan batu } \\
\text { berkumpul } \\
\text { menjadi tembok }\end{array}$ & $\begin{array}{l}\text { with come together } \\
\text { of all efforts, } \\
\text { purpose, ideals, } \\
\text { intentions will be } \\
\text { achieved }\end{array}$ \\
\hline & $\begin{array}{l}\text { Waun ngaloan } \\
\text { erdad rir ohoi }\end{array}$ & $\begin{array}{c}\text { sebagai laba-laba } \\
\text { membuat } \\
\text { sarangnya }\end{array}$ & $\begin{array}{l}\text { work that do } \\
\text { continously, fast, } \\
\text { and regular to } \\
\text { complete }\end{array}$ \\
\hline \multirow[t]{2}{*}{$\begin{array}{l}\text { Work and } \\
\text { negative } \\
\text { work }\end{array}$} & $\begin{array}{l}\text { Uud naklahoa } \\
\text { bulin matan }\end{array}$ & \begin{tabular}{l}
\multicolumn{2}{l}{ memasukkan } \\
kepala $\quad$ kita \\
melalui lubang \\
jarum
\end{tabular} & $\begin{array}{l}\text { doing impossible to } \\
\text { succees work }\end{array}$ \\
\hline & $\begin{array}{l}\text { Man hob en'or } \\
\text { lan lelean, ne } \\
\text { wu'ut hob } \\
\text { refla tahit } \\
\text { ngalaman }\end{array}$ & $\begin{array}{l}\text { burung masih } \\
\text { berterbangan di } \\
\text { angkasa dan ikan } \\
\text { masih berenang } \\
\text { di laut dalam }\end{array}$ & $\begin{array}{l}\text { plan grandiose } \\
\text { which have not been } \\
\text { certainly succeeded }\end{array}$ \\
\hline \multirow[t]{2}{*}{$\begin{array}{l}\text { Luck } \\
\text { Situation }\end{array}$} & $\begin{array}{l}\text { Met ngalavar } \\
\text { ne lair ensong }\end{array}$ & $\begin{array}{l}\text { meti yang luas } \\
\text { dan tanjung yang } \\
\text { menjorok ke laut }\end{array}$ & $\begin{array}{l}\text { get sustenance that } \\
\text { abundant }\end{array}$ \\
\hline & $\begin{array}{l}\text { Lek su entub } \\
\text { fra hangan fak }\end{array}$ & $\begin{array}{lr}\text { jatuh di cabang } \\
\text { empat } & \text { pohon } \\
\text { kayu besi } & \\
\end{array}$ & $\begin{array}{l}\text { people who have } \\
\text { trouble but get help } \\
\text { from others }\end{array}$ \\
\hline \multirow[t]{2}{*}{$\begin{array}{l}\text { Suffering } \\
\text { Situation }\end{array}$} & $\begin{array}{l}\text { U let lor vuvur } \\
\text { ne u tai } \\
\text { kerbau hungar }\end{array}$ & $\begin{array}{l}\text { meniti punggung } \\
\text { ikan paus dan } \\
\text { berdiri pada } \\
\text { tanduk kerbau }\end{array}$ & $\begin{array}{l}\text { assume it's hard and } \\
\text { miserable which is } \\
\text { really hard }\end{array}$ \\
\hline & $\begin{array}{l}\text { Ngangaar yaf } \\
\text { ro enavun ve'e }\end{array}$ & $\begin{array}{l}\text { membongkar api } \\
\text { malahan } \\
\text { membakar kebun }\end{array}$ & $\begin{array}{l}\text { Good will avoid } \\
\text { danger even got } \\
\text { more severe danger }\end{array}$ \\
\hline
\end{tabular}

\section{CONCLUSION}

Proverb means delivery of a something indirectly message that containing social norms. The messages in provers of Kei are classified according to character of the people, the people with their behavior, the people with around situation. All of these illustrate various aspects in the life of Kei people according to their customary law, namely the law of Larwul Ngabal. 


\section{ACKNOWLEDGMENT}

This article was written based on the research conducted by the support of Rector of Musamus University and the Dean of Teacher Training and Education Faculty of Musamus University, so the writers convey the big thank for the material and spiritual support.

\section{REFERENCES}

[1] Alfian, Persepsi Masyarakat tentang Kebudayaan. Jakarta: Gramedia, 1985.

[2] Franz Josef Eilers, Berkomunikasi antara Budaya. Ende: Nusa Indah, 1995.

[3] C. A. Winarsih, S., Narahawarin, M. F., Bawawa, M., Marnina, M., \& Fenanlampir, "Portrait of Environmental Conditions in Urban and Rural Areas in Abdur Arsyad's Stand-up Comedy," 1st Int. Conf. Soc. Sci. (ICSS 2018). Atl. Press., vol. 226, pp. 1329-1332, 2018.

[4] M. Mulyo, I. A., \& Marnina, “An Analysis Of Students'error In Using Personal Pronoun As Subject And Object At Seventh Grade Students Of SMP Negeri 6 Merauke Academic Year 2018/2019," Musamus J. Lang. Lit., vol. 1, no. 2, pp. 47-62, 2019.

[5] M. Bawawa, "Menggunakan Grafik Dinding sebagai Media untuk Mengembangkan Penguasaan Kosakata Siswa," Dr. Diss. Pascasarj., 2017.

[6] J. P. Rahail, "Larwul Ngabal: hukum adat Kei, bertahan menghadapi arus perubahan," Yayasan Sejati, vol. 1, 1993.

[7] E. Dobrovol'skij, D., \& Piirainen, Figurative language: Crosscultural and cross-linguistic perspectives. Brill, 2005.

[8] S. Sauhenda, A., Marnina, M., Riwu, L., Santo, Z., \& Monika, "The Ability to Understand Narrative Text of The Second Semester Students of Indonesian Language and Literature Academic Year 2017/2018 of Musamus University," 1st Int. Conf. Soc. Sci. (ICSS 2018). Atl. Press., vol. 226, pp. 1388-1393, 2018.

[9] J. Tetelepta, Struktur Bahasa Kei. Pusat Pembinaan dan Pengembangan Bahasa, Departemen Pendidikan dan Kebudayaan., 1985.

[10] M. Rosenberg, S., \& Koen, "Norms of Sequential Associative Dependencies in Active Declarative Sentences.," 1968. 